\title{
Den historiske fortæller
}

\section{Om fortællerens problem i Rødt og sort}

\begin{abstract}
Ak! Dette er ulykken ved alt for megen civilisation! I en alder af tyve år er en ung mand, hvis han blot har nogen uddannelse, milevidt fra den utvungenhed uden hvilken kærligheden ofte kun er den kedeligste af alle pligter. ${ }^{1}$
\end{abstract}

Denne ideologiske fortællerkommentar indtræffer i Rødt og sort i forbindelse med hovedpersonen Julien Sorels kærlighedsaffære med den noget ældre borgmesterfrue Mme de Rênal. Fortælleren kritiserer den måde, Julien forfører hende på, hvor han ud fra en følelse af pligt indlader sig med borgmesterfruen. Kommentaren er karakteristisk for den fremtrædende fortællerinstans i Stendhals roman. Gennem hele Rødt og sort intervenerer og kommenterer fortælleren handlingsforløbet. Han er tilbøjelig til at moralisere og udsige almene sandheder, og han er også som ovenfor patroniserende og bedrevidende over for sin helt Julien.

Der har i romanens receptionshistorie været en tendens til at læse fortællerens interventioner sammen med en generel analyse af Stendhals særegne stemme og stil. Derved er karakteristikken af fortælleren blevet sat i forbindelse med Stendhals andre romaner, hans biografi og tænkning generelt. ${ }^{2}$ Særligt Victor Brombert har grundigt beskrevet fortællerens idiosynkratiske og polemiske stemme i Rødt og sort samt hans alvidenhed og psykologiske kompetence. Bromberts karakteristik beskriver dog ikke fortællerens rolle udtømmende. Fortælleren fremtræder nemlig i begyndelsen som en selvstændig karakter i romanen, og man kan ud fra de almene sandheder, han udsiger, og hans følelsesmæssige engagement historisere stemmen i forhold til en romantisk diskurs fra Rousseau. Jeg argumenterer altså for, at fortællerstemmen er en ideologisk stemme, som indeholder historiske diskursive træk, der er forskellige fra Stendhals øvrige romaner og tekster, og som retter sig specifikt ind i romanens problematik.

Når man opfatter fortælleren som en selvstændig stemme i teksten med særlige værdier og holdninger, bliver han en del af romanens spil og som 
sådan forskellig fra forfatterens holdninger. Denne vinkel indebærer også, at fortælleren kan komme i moralsk konflikt med hændelserne på fortællingens niveau. Det er denne type fortæller, Wayne Booth beskriver som upålidelig, fordi der kan opstå en diskrepans mellem den eksplicitte fortællers normer og de normer, den implicitte fortæller iscenesætter på fortællingens niveau. ${ }^{3}$ Forskellen opstår typisk mellem romanens handling eller karakterernes indre monolog og de evaluerende og kritiske kommentarer, som fortælleren fremfører, men den kan også fremkomme ved, at fortælleren er tavs, det vil sige, at han undlader at kommentere forløbet, hvilket Stendhals fortæller er særligt berømt for.

Jeg vil bruge analysen af fortælleren til litteraturhistorisk at placere Stendhal på vej ud af en romantisk diskurs. Under inddragelse af Christopher Prendergasts og Peter Brooks' læsninger vil jeg vise Stendhals romantiske side. ${ }^{4}$ Begge forstår de fortællerens forhold til repræsentationen som et magtforhold, og som jeg afslutningsvis vil komme ind på, er det bestemmende for deres syn på forholdet mellem roman og historie, og den måde fortælleren er historiseret. Det gør altså en forskel, om man betragter fortælleren som en autoritet, eller om man flytter optikken og ser ham som en selvstændig stemme i teksten.

\section{Fortællerens autoritet}

Læsninger, der fokuserer på, at fortælleren er en alvidende og kontrollerende instans i Rødt og sort, undlader gerne at gøre opmærksom på, at denne i begyndelsen af romanen præsenteres som en karakter, der tilhører diegesen. Jeg benytter Gerard Genettes distinktion mellem en homodiegetisk og en heterodiegetisk fortæller. ${ }^{5}$ Den homodiegetiske fortæller er en karakter, der tilhører diegesen og derfor har en begrænset viden i forhold til de andre karakterer i fortællingen. Hvorimod en heterodiegetisk fortæller står uden for diegesen og har indsigt i karakterernes tanker og følelser.

Fortælleren beskriver sig selv som liberal i modsætning til den konservative borgmester M. de Rênal, og han tænker tilbage på ballerne i Paris, mens han nyder udsigten fra udkigspunktet i Verrières, landsbyen hvor det meste af romanens første del foregår. ${ }^{6}$ Han er en kronikør, der gengiver fortællingen som et øjenvidne, og ved at beskrive sig selv som liberal afslører han sin ideologiske position. Han indsætter sig selv i en specifik historisk problematik i restaurationsperioden i Frankrig, hvor den ideologiske konflikt udspandt sig mellem konservatismen, der ville føre tiden tilbage til før den franske revolution, og liberalismen, der ville videreføre revolutionens humanistiske ide- 
aler. Fortællerens rolle som kronikør skaber gennem hele romanen en samtidighed mellem handlingsforløbet og fortællerens kommentarer. Fortælleren udtrykker også et had til den offentlige opinion. Han er kosmopolit og har derfor et ydre blik på landsbyens forhold. Har man levet i »denne store republik man kalder Paris«, er det umuligt at opholde sig i Verrières på grund af den offentlige menings tyranni. ${ }^{7}$

Denne initiale fortællerkarakteristik er inkonsistent, fordi fortælleren samtidig er heterodiegetisk. Han har en alvidenhed i forhold til sine karakterer, hvis tanker og følelser han har indsigt i. Denne dobbelte placering inden i og uden for diegesen bliver ofte forbigået i receptionshistorien, sandsynligvis fordi dobbeltheden opfattes som værende netop inkonsistent. Men derved overser man, at den homodiegetiske fortæller fremhæver, at romanens univers er relativt, og at placeringen af fortælleren inde i diegesen bringer ham i spil i forhold til fortællingen og problematiserer hans autoritet. Fortællerens position inden for romanens tid og rum gør ham til et historiseret og engageret individ, der er tæt på begivenhederne, og som gør den heterogene fortællers transcendentale position uden for romanens tid og rum utroværdig.

Christopher Prendergast beskæftiger sig ikke med denne beskrivelse af fortælleren. Han opfatter ham som en magtinstans, der har kontrol over repræsentationen. Fortælleren er i Prendergasts forståelse en ideologisk figur, der står uden for det repræsenterede univers, og som styrer begivenhedernes gang. Prendergasts læsning bygger på en forestilling om, at romanens repræsentation kan mime den offentlige opinion i et samfund på et givet tidspunkt og på forskellig måde bryde med den:

„Fortællingens afgørende øjeblikke er (præcist) dens 'atypiske’ øjeblikke. Faktisk kan man med Leo Bersani sige, at det strengt 'mimetiske' stof i Rødt og sort (repræsentationen af virkeligheden ved hjælp af en række sammenhængende typer: borgerskabet i Verrières, aristokraterne fra de la Môles salon) hovedsagelig tjener som kontrasteffekt ved at fremhæve de handlinger eller de erfaringer, der undergraver de opfattelser af virkeligheden, som illustreres og bekræftes af disse forskellige sociale typer. Disse handlinger er selvfølgelig primært overskridelser af moralske koder, foranlediget af impulser og ønsker, som er forbudte eller ikke anerkendte af samfundet: Juliens forbrydelse, Louises utroskab, Mathildes lidenskab. $\ll^{8}$

Prendergast henviser til nogle afgørende normbrud i romanen. Det drejer sig om borgmesterfruen Louise de Rênals kærlighed til Julien, der er ansat som huslærer for borgmesterens børn, den til tider groteske kærlighed, som ari- 
stokraten Mathilde de la Môle har til tømrersvenden Julien og endelig Juliens uforklarlige mordforsøg på Mme de Rênal, som jeg vender tilbage til. Med sin læsning viser Prendergast, at sædeskildringen danner baggrund og de normbrydende handlinger forgrund i romanen. Prendergast funderer sin analyse på en strukturel og statisk forståelse af romanen, hvor fortælleren er tilbagetrukket og ironisk i forhold til den socialitet, han beskriver. Opfattelsen af fortælleren som et magtfuldt og kontrollerende subjekt er inspireret af Roland Barthes' syn på repræsentation. Han beskriver selv Barthes' teori i The Order of Mimesis, og jeg vil derfor foretage en kort teoretisk ekskurs for at uddybe Prendergasts forståelse af fortællerens rolle i romanen.

\section{Den triangulære repræsentationsmodel}

Roland Barthes er kritisk over for litteraturens mulighed for at generere erkendelse gennem mimesis. ${ }^{9}$ Mimesis er et aristotelisk begreb, der refererer til litteraturens gengivelse og strukturering af virkeligheden i et meningsfyldt forløb. Aristoteles rangerer litteraturen over historieskrivningen, fordi han mener, at den er i stand til at strukturere et forløb, der giver indblik i en dybereliggende logisk struktur i virkeligheden og i individet end den historiske og kontingente virkelighed. Aristoteles forstår mimesis positivt som en værdifuld kognitiv proces, hvor individet ved hjælp af genkendelse lærer om realiteten og dens strukturer. Et stridsspørgsmål i receptionen af Poetikken har været, om man skal forstå den dybereliggende kausale orden ud fra Aristoteles' teleologiske verdenssyn, som det kommer til udtryk i Fysikken, eller ud fra Aristoteles' Retorik. Denne konflikt er afgørende, fordi der i Aristoteles' tænkning er en klar adskillelse mellem videnskab, som er en undersøgelse af naturen ud fra logik og nødvendighed, og retorik, som vedrører det sociale og kun kan forstås ud fra begrebet om sandsynlighed. Strukturerer litteraturen altså en sandsynlig og social orden eller en logisk og naturlig orden, når den repræsenterer virkeligheden. I Roland Barthes' syn på repræsentation er det en social orden, der repræsenteres i det litterære værk. På samme måde som i den retoriske tale opnår forfatteren læserens velvilje og accept, når han ved et indgående kendskab til doxaen, det vil sige de alment accepterede meninger, der gælder i et samfund på et givet tidspunkt, er i stand til at strukturere et forløb, der mimer doxaen. Genkendelsen hos læseren gælder ikke kun forløbet, men alle de retoriske virkemidler en roman er bygget op af som for eksempel dialogen, fortællerkommentaren og beskrivelsen. I udvekslingen mellem læser og tekst opstår der et doxalt rum, hvor doxaen reflekteres frem og tilbage, baseret på en fælles kontrakt, en fælles virkelighedsopfattelse. 
Problemet er, at genkendelsen derved ikke fører til viden, men blot bekræfter det lukkede normsystem i socialiteten. Barthes forholder sig altså skeptisk til litteraturens mulighed for at generere erkendelse. Når plotstrukturen ikke er funderet på en naturlig orden, en logisk og kausal sekvens af hændelser, reduceres forløbet til en moralsk orden, til ideologi. Den realistiske roman fremviser således ikke en dybere virkelighed, men gentager blot samfundets gældende normer. Det litterære værk bliver »en kopi af en kopi«.

Barthes' syn på repræsentation er derfor ideologikritisk. Han beskriver i essayet »Diderot, Brecht, Eisenstein« en triangulær repræsentationsmodel, som funderer Prendergasts analyse. ${ }^{10}$ Barthes viser, hvordan det repræsenterende subjekt udskærer det synsfelt, som læseren/tilskueren får indsigt i. Han opfatter repræsentation som en både spatial og visuel praksis, hvor subjektet fra en hævet position kontrollerer, hvad der skal være present, og hvad der skal være fraværende i synsfeltet. Barthes forholder sig kritisk til repræsentation, fordi det repræsenterende subjekt udøver en magt over læseren/ tilskueren i den censurering, enhver repræsentation består af.

Prendergast bruger Barthes' model til at vise, hvordan fortælleren fra en hævet og magtfuld position sætter det litterære forløb i Rødt og sort. Fortælleren er ideologisk i konflikt med den offentlige opinion og ved at veksle imellem en sandsynlig og en usandsynlig repræsentation destabiliserer han den sociale orden og tvinger læseren til at opfatte virkeligheden på nye måder. Louises utroskab, Mathildes kærlighed og Juliens mordforsøg er således usandsynlige handlinger, der provokerer doxaens krav om sandsynlighed.

\section{Fortælleren og offentligheden}

Prendergast historiserer sin strukturelle beskrivelse af romanen ved at forankre den i den historiske kommunikationssituation mellem forfatter og publikum. Ved blandt andet at undersøge romanens dårlige modtagelse, den blev betragtet som både usandsynlig og umoralsk, kan han ud fra den sige noget generelt mentalitetshistorisk om den offentlige opinion i Restaurationsperioden. Men Prendergast ser i læserhenvendelsen det vigtigste argument for Stendhals leg med doxaen og læserforventningerne. Han citerer en af de berømte interventioner fra fortællerens side. Det er kort efter, at den adelige Mathilde har sovet sammen med tømrersvenden Julien:

»Resultatet af denne vanvidsnat var at hun troede at det var lykkedes hende at triumfere over sin kærlighed. Denne side vil på mere end én måde skade den ulykkelige forfatter. De kolde sjæle vil anklage ham for 
uanstændighed. Han udsætter ikke de unge piger der brillerer i Paris' saloner, for den fornærmelse at antage at de er i stand til at nære de samme vanvidsfølelser som fornedrer Mathildes karakter. Denne person er ren fiktion og tilmed opdigtet langt uden for de sociale vaner der vil sikre det 19. århundredes civilisation en så fremtrædende plads blandt alle andre århundreder (...). Da vi nu er enige om at Mathildes karakter er umulig i vort århundrede som er lige så forsigtigt som dydigt, er jeg mindre bange for at vække irritation ved at fortsætte beretningen om denne elskelige piges gale streger. $«^{11}$

Prendergast mener, at denne læserhenvendelse er forankret i en »historisk basis«, fordi fortælleren appellerer til læserens holdninger og værdier uden for romanen. Han kan således karakterisere fortælleren som en »formidler af doxa«, fordi fortælleren står på grænsen mellem offentligheden og romanens repræsenterede univers. ${ }^{12}$ Fortælleren kan i denne mellemposition mime og provokere doxaen, og det gør han ved at iscenesætte disse "vanvittige« handlinger, der er umulige at integrere i restaurationsperiodens normsystem.

Eftersom fortælleren er en »formidler af doxa« og udtrykker sin subjektivitet gennem det sociale sprog, ser Prendergast en lighed mellem Julien Sorels adskillelse mellem indre og ydre, det notoriske hykleri i Rødt og sort, og fortællerens forhold til læseren:

"Reproduktionen af denne sprogbrug [doxaens topoi] er for forfatteren til Rødt og sort uundværlig for opfattelsen af romanen som en »beretning fra det 19. årh.«, og dens herredømme er en nødvendig betingelse for heltens udvikling. Men for både forfatter og helt er knebet i Rødt og sort at bibeholde en smule frihed, mens de samtidig indgår i det, der truer denne frihed: hvorledes Julien taler til de andre karakterer, og hvordan Stendhal taler til sine læsere er to sider af det samme dilemma og det samme spil. «13

Både fortæller og helt opnår altså en frihed i forhold til socialiteten ved at hykle. Fortælleren viser hykleriet i karaktertegningen af Julien ved brug af indre monolog. Der er en forskel mellem, hvad han tænker, og hvad han sier. Fortællerens egen subjektivitet kommer derimod kun indirekte til udtryk gennem ironi som i den ovenstående læserhenvendelse eller ved brug af ellipsen, den bevidste udeladelse. Ironien distancerer fortælleren fra den mimetiske kontrakt og de stereotype fraser, han bruger til at skabe virkelighedsillusionen med, mens han andre steder helt bevidst undlader at kommentere handlingsforløbet. Fortælleren forbigår for eksempel Julien Sorels uforklar- 
lige mordforsøg på Mme de Rênal i tavshed. Gennem denne provokation udtrykker fortælleren sin subjektivitet. Den indforståede læser kan således le bag om ryggen på den offentlige opinion sammen med fortælleren. Prendergast glider i det ovenstående citat mellem fortæller og forfatter, fordi han argumenterer for, at den provokerende iscenesætter af romanen er forenelig med Stendhals normer i øvrigt.

\section{Den rejsende moralist}

Prendergasts brug af Barthes' model i forståelsen af fortælleren i Rødt og sort skaber en distance mellem fortælleren og repræsentationen. Læserhenvendelsen, ironien og ellipsen er retoriske greb, der fremhæver fortællerens placering øverst i Barthes' trekant som den kontrollerende instans, der er på afstand af begivenhederne. Denne teoretiske vinkel bevirker, at Prendergast må udgrænse alle fortællerens konkrete vurderinger og holdninger til handlingsforløbet; han reducerer dem til doxa. Derved forbigår han, at fortællerens stemme er selvstændig og fremtrædende i romanen og meget lidt forenelig med den provokerende iscenesætter. Fortællerens subjektive værdidomme er nemlig moralske. For eksempel udtrykker fortælleren følgende holdning til præsteseminariet, som Julien er blevet optaget på:

»Men hvad nytter det at nævne hans venner, hans fjender? Alt dette er grimt jo mere sand hensigten er. Og dog er det de eneste morallærere folket har, og hvad skulle der blive af det uden dem? Vil avisen nogen sinde kunne erstatte sognepræsten? « ${ }^{14}$

Fortælleren er gennem hele romanen imod civilisation, hykleri, smålighed og egoisme og for naturlighed og moral. Det er denne ideologi, der funderer fortælleren som moralist, og det er disse værdier, der er med til at forankre fortælleren i en historisk diskurs fra Rousseau.

I begyndelsen af romanen fremhæves fortællerens position i forhold til fortællingen. Udover at han præsenteres som tilhørende diegesen, indledes romanen med et dobbeltperspektiv, hvor fortællerinstansen udspaltes mellem en rejsende og en fastboende. Dobbeltperspektivet påvirker også narrationen, der får karakter af en rejsebeskrivelse.

„Den lille by Verrière kan gå for at være en af de smukkeste i Franche Comté. Dens hvide huse med de spidse tage af røde teglsten breder sig på et bakkedrag hvor klynger af kraftige kastanjetræer markerer selv de 
mindste bugtninger. Floden Doubs løber et par hundrede fod under fæstningsvoldene der i sin tid blev bygget af spanierne og som nu ligger i ruiner. $\ll^{15}$

Den rejsende fortæller har et idyllisk blik på byen og udtrykker en stor viden om egnens geografiske og historiske forhold. Dette blik kommer dog under et gevaldigt pres fra den fastboende, som beskriver larmen fra borgmesterens sømfabrik, der betjenes af landsbyens unge kvinder, og de mandlige karakterers smålighed og egoisme. Men kort efter intervenerer den rejsendes diskurs igen i fremstillingen: „På den anden side dannes horisontlinjen af Bourgognes højdedrag som man skulle tro var skabt for at fryde blikket. Denne udsigt får den rejsende til at glemme den forpestede atmosfære af smålig griskhed som begynder at kvæle ham. «16 Den samme modstilling gentages i fortællerens bemærkning: »Give indtægter er den grund som afgør alt i denne lille by som De [den rejsende] syntes var så køn. ${ }^{17}$

I romanens begyndelse etableres en modsætning mellem den rejsendes møde med landsbyen som noget pittoresk og ukendt og så den fastboende, der kender byens indbyggere. Men dobbeltperspektivet er en iscenesættelse af en bevægelse, som fortælleren selv har undergået. Det viser sig blandt andet ved, at han tænker tilbage på ballerne i Paris, mens han nyder udsigten fra Verrières promenade. Intentionen med at indlede fortællingen med den rejsendes perspektiv skaber således ikke kun en kontrasteffekt. For dobbeltperspektivet viser fortællerens initiale bevægelse væk fra Paris mod Verrières. En bevægelse der fremstår som en projektiv bevægelse efter mening, og som kontrasteres af en retrospektiv viden og desillusion.

Selv om skildringen af beboerne i Verrières er yderst negativ og moralsk fordømmende, så vender fortællerens glæde ved naturen tilbage i løbet af fortællingen. Fortællerens moralske fordømmelse af særligt de mandlige karakterer i landsbyen modstilles nemlig af et behag ved beskrivelsen af Juliens og Mme de Rênals kærlighed. Romanens mest positivt valoriserede sekvens er beskrivelsen af Julien og Mme de Rênal, der jager sommerfugle i Vergy, hvor borgmesterens sommerresidens er lokaliseret. Når Julien tænker tilbage på sit liv fra sin fængselscelle, betragter han livet i Vergy som den lykkeligste periode. Minderne om Vergy flyver gennem hovedet på ham, umiddelbart inden han halshugges. ${ }^{18}$ Fortælleren forsøger at distancere sig fra Mme de Rênals og Juliens naivitet, men hans tydelige moralske behag ved situationen afslører sig ved, at naturbeskrivelserne fletter sig sammen med karakterernes handlinger og tanker: 
"Julien havde for sit eget vedkommende levet som et veritabelt barn siden han var kommet på landet, og var lige så lykkelig for at jage sommerfugle som sine elever. Efter al denne tvang og drevne politik var han alene, langt fra mændenes blikke, og da han instinktivt ikke nærede nogen frygt for Fru de Rênal, overgav han sig til glæden ved at leve, som er så stærk i hans alder, og det blandt verdens smukkeste bjerge.

Allerede fra Fru Devilles ankomst forekom det Julien at hun var hans veninde. Han skyndte sig at vise hende det udkigspunkt man har fra den fjerneste ende af den nye allé under de store valnøddetræer: det er faktisk lige så storslået om ikke mere end det skønneste Schweiz og de italienske søer kan frembyde. Hvis man bestiger den stejle skråning der begynder nogle skridt derfra, når man snart frem til floden. Det var hen til disse spidse klipper at Julien, lykkelig, fri og endda noget mere, husets konge, førte de to veninder og nød deres begejstring over dette pragtfulde syn. $\ll^{19}$

Det idylliske kommer altså under pres fra begyndelsen af romanen, men vender alligevel tilbage undervejs i fortællingen. Fortællerens behag ved Julien og Mme de Rênal er en glæde ved de naturlige følelser og det naive, og beskrivelserne har affinitet til Rousseaus idylliske naturbilleder. ${ }^{20}$ Fortællerens placering inde i diegesen som en rejsende og en kronikør, der er følelsesmæssigt engageret i handlingsforløbet og bundet til sine værdier, gør ham til et historiseret individ med begrænsninger. Denne karakteristik kontrasterer Prendergasts distancerede og overlegne fortæller.

\section{Saint Giraud og Rousseau}

En samtale, der indtræffer i den drosche, der bringer Julien fra Verrières til Paris, understøtter fortolkningen af fortælleren som en selvstændig karakter, der er involveret i fortællingen. Julien møder i droschen Saint Giraud, en fritænker og velhavende æstetiker. Han viser sig at have mange ligheder med fortælleren i romanen, og det er disse ligheder, der accentuerer forskellene. Giraud beretter om, hvordan han for nogle år tilbage købte et gods ved Rhônefloden for at slippe for de politiske stridigheder i Paris, men på grund af chikane fra lokalbefolkningen er han blevet nødt til at vende tilbage til Paris. Under sit ophold blev han mod sin vilje tvunget til at tage politisk stilling, og han valgte af strategiske grunde at være liberalist. Rejsen fra Paris til Rhône gentager i forskudt form fortællerens rejse fra Paris til Verrières, og 
hans problemer med lokalbefolkningen og hans politiske observans svarer til fortællerens:

»Jeg flygter fra det rædselsfulde liv man fører i provinsen. Jeg elsker de kølige skove og den landlige ro, som du [Falcoz, en tredje karakter i droschen] ved; du har ofte anklaget mig for at være romantiker. Jeg ville ikke for min død snakke politik, og det er politikken der jager mig bort.

Men hvilket parti hører du til?

Intet, og det er det der bringer mig i ulykke. Her har du al min politik: Jeg elsker musik, maleri, en god bog er en begivenhed for mig; jeg fylder fireogfyrre år. Hvor lang tid har jeg tilbage? ${ }^{21}$

Det nævnes to gange i den korte dialog, at Saint Giraud er fireogfyrre år gammel, hvilket svarer til Stendhals (f. 1783) alder i 1827. Årstallet, som det fremgår af bogens forord, er sammenfaldende med tidspunktet for nedskrivningen af romanen. ${ }^{22}$ Fritænker, æstetiker og livsnyder passer også godt til Stendhals livsfilosofi. Disse åbenlyse selvbiografiske referencer giver dog ikke Saint Girauds udsagn en privilegeret status i romanen som forfatterens talerør. Det er en del af Stendhals maskebal. Men de fremhæver fortælleren som en selvstændig stemme i teksten. For samtidig med, at der markeres en række ligheder mellem fortælleren og Saint Giraud, bliver forskellene også tydelige, særligt forskellen mellem den moralske fortæller og den fritænkende Saint Giraud. Med Wayne Booths begreb om upålidelighed in mente kan man sige, at der opstår en diskrepans mellem fortællerens normer og Saint Girauds normer, hvilket accentuerer forskellen mellem den implicitte fortæller og den eksplicitte.

Udover de selvbiografiske referencer er der to kulturelle referencer til Jean Jacques Rousseau i kapitlet. Kort før afrejsen er Julien flygtet fra borgmesterens hus, fordi han er blevet opdaget i Mme de Rênals soveværelse og for at ryste eventuelle forfølgere af sig, har han taget en afstikker til Genève, Rousseaus fødeby. Droschen ankommer også til Rue J.J. Rousseau i Paris, hvor Rousseau endte sine dage langt fra de landlige glæder. Samtalen foregår netop i en drosche, som symboliserer mobiliteten i samfundet. Byen er det, der muliggør rejsen tilbage til landet og transformationen af det landlige til noget pittoresk og idyllisk, ligesom det muliggør den sociale mobilitet, som Juliens symbolske rejse mod magten i Paris viser. Denne rejsen frem og tilbage mellem land og by gentages senere i romanen i forbindelse med Juliens ønske om at vende tilbage til landet. Fortælleren sættes på denne indirekte måde i forbindelse med Rousseau. Forskellen mellem Saint Giraud og fortæl- 
leren og begges desillusionerede møde med det landlige er en del af Stendhals ønske om at frigøre sig fra Rousseau, se dérousseauiser. ${ }^{23}$

\section{Fortælleren og den politiske historie}

Fortælleren er i Christopher Prendergasts læsning den ideologiske iscenesætter, der manipulerer doxaen, mens jeg beskriver, hvordan fortællerens følelser og værdier fremhæves i teksten. Begge læsninger er statiske beskrivelser af fortælleren, der forbigår den udvikling, som han gennemgår i forhold til handlingsforløbet. Den væsentligste udvikling skabes i forholdet mellem fortæller og helt, fordi det har karakter af et fader/søn forhold. Fortælleren er romanen igennem patroniserende og bedrevidende over for sin helt, og han nyder at gøre opmærksom på Juliens manglende indsigt og kommenterer ivrigt på hans fejlfortolkninger og fejltagelser. Der findes også en række distancerende markører, der viser en forskel mellem Juliens normer og fortællerens normer. Han beskriver ham for eksempel som »vor oprørske plebejer « ${ }^{24}$ Men i romanens vendepunkt, Juliens uforklarlige mordforsøg på Mme de Rênal, sker der en afgørende udvikling i forholdet mellem fortæller og helt.

Det er denne dynamik, som Peter Brooks beskriver i sin analyse af fortællerinstansen. Brooks' læsning af Rødt og sort er en del af en større kritik af strukturalismens spatiale og statiske litteraturforståelse. I modsætning til Prendergast undersøger Brooks romanens dynamik. Han læser dynamikken mellem fortæller og helt i forhold til restaurationsperiodens legitimitetsproblemer. ${ }^{25}$

Peter Brooks mener, at Rødt og sort er en af de første romaner, der udforsker forholdet mellem individuel biografi og kollektiv historie. Julien Sorel er en karakter, der ikke former sit livsplot på baggrund af familie eller tradition, men i forhold til de sociale og politiske omstændigheder. Hans identitet er dannet af to historiske og litterære forbilleder, Napoleon og Rousseau, men han vælger af opportunistiske grunde at blive præst. Det gør han, fordi han vokser op i restaurationens Frankrig, hvor karrieremulighederne er bedst inden for kirken. Han foretager altså en adskillelse mellem indre og ydre og hykler sig vej frem i samfundet. Han er et "monster«i den etablerede orden, som romanen flere gange fremhæver. Julien fornægter altså sit ophav og skjuler sine forbilleder for omverdenen med henblik på at komme frem i verden, og på denne rejse kommer han i forbindelse med en række faderfigurer, som sikrer hans sociale opstigning. Brooks ser derfor Juliens ambition som motoren i romanen, og det er i kontrast til Juliens begær, at romanens grundlæg- 
gende tema gestaltes: Spørgsmålet omkring legitimitet, autoritet og faderskab. Dette tema knytter Brooks til den store politiske historie. Han formulerer det grundlæggende spørgsmål i restaurationsperiodens Frankrig som: »Hvem tilhører Frankrig?« Genindsættelsen af det bourbonske kongehus efter den franske revolution og Napoleons kejserdømme var en regressiv bevægelse, der ikke længere havde nogen legitimitet, og som stod i modsætning til den sociale dynamik, der var i samfundet. Julirevolutionen anno 1830 var som sådan helt uundgåelig. Det er i dynamikken mellem ungdommelig energi og faderskab, mellem revolution og restauration, mellem politik og sæder, at Brooks finder romanens plot.

Plottet finder han også i romanens udsigelse, hvor legitimitetsproblemet afspejler sig i fortællerens autoritet:

"Alle Stendhals romaner viser, hvordan den faderlige autoritet mislykkes i forhold til hovedpersonernes liv, og samtidig beskriver de fortællerens bestræbelse på at råde bod på miseren ved selv at være den perfekte fader, ham som kan opretholde samtalen med sin søn. Der kommer dog et tidspunkt i alle romanerne, hvor hovedpersonen også må glide væk under fortæller-faderens kontrol. $«^{26}$

Brooks' tese er, at fortælleren mister sin autoritet i og med Juliens mordforsøg på Mme de Rênal. Hvor Prendergast læser skuddet og fortællerens tavshed som en kølig iscenesættelse af usandsynlighed, læser Brooks skuddet som en handling, der inverterer magtforholdet mellem fortæller og helt. Fortællerens tavshed er udtryk for en impotens, der markerer et ophør af faderens samtale med sin søn. Fortælleren bliver derved sat ind i rækken af fædre, hvis autoritet Julien glider væk under, og skuddet bliver det afgørende øjeblik i narrationens dynamik. For ikke alene halshugges fortællerinstansen, selve romanens aristoteliske plot, der meningsfyldt kan gestalte en sammenhæng mellem liv og plot, bliver det også. Det er efter skuddet ikke længere muligt at konstruere en sammenhængende og meningsfuld beskrivelse af Juliens livsforløb.

Sagen er den, at Julien mod slutningen af romanen har opnået alt. Marquis de la Môle har på grund af Mathildes graviditet været tvunget til at gøre Julien adelig. Julien de la Vernaye, som han nu hedder, har således fået Paris' mest eftertragtede kvinde, og han har skiftet den sorte præstekåbe ud med løjtnantens røde dragt. Min roman er færdig, konkluderer Julien, samtidig med, at han er ved at overbevise sig selv om, at han er en legitim søn af en adelig, der har holdt sig skjult i bjergene omkring Verrière under Napoleon. Som Brooks påpeger, er det politiske og overskridende derved blevet totalt 
udgrænset i romanen. Juliens ambitioner kan forklares som en nostos, et ønske om at vende tilbage til hans retmæssige position i samfundet, og det er den mindst overskridende af alle narrative bevægelser. ${ }^{27}$ Ordenen er genoprettet og det narrative materiale opbrugt. Juliens nye ophav kaster et meningsfyldt og forklarende lys tilbage på romanens handling. Men selv om Juliens roman er færdig, er Stendhals det ikke. Marquis de la Môle modtager et brev fra Mme de Rênal, som hun har skrevet under tvang af en jesuitisk præst. Brevet beskriver Julien som en opportunist, der ved at forføre og hykle bemægtiger sig en position i de sociale sammenhænge, som han indgår i. Efter at Julien har læst brevet, som i udpræget grad beskriver ham som et "monster», tager han en rask beslutning, der vanskeligt kan motiveres rationelt, for han vender tilbage til Verrière og skyder Mme de Rênal, der dog overlever. Resten af romanen foregår mere eller mindre i Juliens fængselscelle, inden han halshugges. ${ }^{28}$

Skuddet markerer, at den ambition, der har skabt romanens plot, ophører. I fængslet mener Julien, at hele hans parisiske karriere og ægteskab med Mathilde har været en fejltagelse. Han helliger sig kun Mme de Rênal og er blevet ligeglad med, hvad andre tænker om ham:

»Ikke blot synes Julien at frasige sig sine forbilleder i disse sidste kapitler, han synes også at bevæge sig hinsides den faderlige fortællers kontrol og vejledning. Der er meget færre fortællerkommentarer i disse kapitler: Faktisk forstummer fortælleren næsten for at overlade scenen til Juliens stort set uforstyrrede monolog. De sidste fire kapitler (42-45), der følger Juliens domfældelse, mangler også titler og indskrifter, en afvigelse fra resten af romanen, som stemmer overens med den bemærkelsesværdige udviskning af fortælllerens diskursivitet og dramatiske tilstedeværelse. Julien har simultant bevæget sig hinsides faderlig autoritet og hinsides romanens plot. Han er ikke længere narrativt materiale: Hans roman er afsluttet, og de sidste kapitlers karakter af »appendix« tjener til at understrege forskellen mellem plot og liv, mellem Juliens roman og Stendhals, mellem autoritativ mening og undergravelse af mening. $\|^{29}$

\section{Fortæller og helt}

Brooks og Prendergast har samme syn på fortælleren frem til skuddet, fordi de opfatter ham som den selvbevidste autoritet, der kontrollerer teksten. Brooks forstår forholdet mellem Julien og fortæller som en magtrelation, der 
udtrykkes i termer som »kontrol«, »vejledning«, »faderlig autoritet« og »samtale med sin søn«. Er det rimeligt at beskrive forholdet mellem fortæller og helt, som et magtforhold mellem fader og søn? Jeg er enig med litteraturkritikeren Dorrit Cohn i, at det er problematisk. ${ }^{30}$ Den heterodiegetiske fortæller opererer på et andet ontologisk plan end helten. De er ikke del af det samme univers, og forholdet er derfor ikke reversibelt og dynamisk. Julien kan hverken tale tilbage til sin fortæller eller slippe ud af tekstens univers. Problemet afspejler sig i Brooks' læsning ved, at skuddet bliver fortolket for radikalt; fortælleren skal som autoritet omstyrtes og halshugges.

Romanen markerer tekstuelt en forskel i forholdet mellem fortæller og helt før og efter skuddet. Det har Brooks ret i. Som vist tidligere sammenblander Stendhal også de to ontologisk forskellige planer ved at placere fortælleren både inden i og uden for diegesen. En lignende metaforisk udveksling iscenesættes, fordi fortællerens holdning til Julien ændrer karakter efter skuddet. Denne udvikling mimer et fader/søn forhold.

Derimod mener jeg ikke, at fortælleren efter skuddet bliver tavs og uden dramatisk tilstedeværelse. For fortælleren giver stadig en række psykologiske forklaringer, og han er stadig ironisk over for Julien. Det gælder for eksempel ved Juliens lidt indbildske og martyragtige forsvarstale, som fortælleren ikke orker at gengive i sin helhed. ${ }^{31}$ Når der er så meget dialog og indre monolog i de afsluttende kapitler, skyldes det naturligvis også, at Julien, på grund af sin indespærring, er frarøvet muligheden for handling. Følgende moralske kommentar viser også fortællerens tilstedeværelse:

»Han var endnu ganske ung, men efter min opfattelse havde han smukke udviklingsmuligheder. I stedet for at gå fra det kærlige til det snedige som de fleste mænd, ville alderen have givet ham den utvungne godhed der kan føle medynk, han ville have frigjort sig fra en vanvittig mistænksomhed... Men hvad nytter disse ligegyldige forudsigelser? «32

En forskel i forholdet mellem fortæller og helt er for mig at se skiftet fra at være patroniserende, men også oprigtigt engageret, til at være ironisk og opgivende. Det er, som om Juliens mangel på ambition og mulighed får fortælleren til at miste interessen for sin helt. Juliens mordforsøg unddrager sig også en psykologisk forklaring og markerer et ophør af den psykologiske diskurs, som fortælleren ellers er så berømt for. Tavsheden understreger fortællerens upålidelighed; han er i spil med romanen, og i denne forstand har Brooks ret i, at det markerer et faderligt kontroltab. Julien bliver voksen, men i en pessimistisk forståelse, hvor man bliver voksen i det øjeblik, man gør noget ufornuftigt, bliver uambitiøs og ikke lever op til forventningerne. 
Fortællerens forandrede syn på Julien afslører sig også ved, at han begynder at omtale ham som en mand, som når Julien har lyttet til en historie fra en de andre fanger: »Hans historie var afskyelig. Den viste et tappert hjerte hvor kun én lidenskab var tilbage, pengenes. Da de var gået, var Julien ikke længere den samme mand. «33 Efter denne samtale konfronteres Julien for alvor med døden. Han bliver grebet af melankoli og har en række tragiske erkendelser om verdens ondskab:

»Der findes ingen naturret; (...) Før loven er der ikke noget naturligt undtagen løvens styrke eller behovene hos det væsen som sulter eller fryser, kort sagt behov... nej, de folk man ærer, er blot slyngler der har være så heldige ikke at blive taget på fersk gerning. (...) En søndag eftermiddag vil han [Juliens far] vise sit guld til alle sine misundere i Verrières. Hvem af jer, vil hans blik sige til dem, ville ikke være henrykt over at have en guillotineret søn til den pris? (...) Jeg elsker sandheden... Hvor er den?... Overalt hykleri eller i det mindste charlataneri, selv hos de dydigste, de største, og hans læber fortrak sig i afsky... Nej, mennesket kan ikke stole på mennesket. (...) »Mine samtidiges indflydelse er stærkest, « sagde han højt og med en bitter latter. »Når jeg taler med mig selv to skridt fra døden er jeg stadig en hykler... Åh, nittende århundrede! « $i^{34}$

Disse erkendelser akkompagnerer fortælleren med en række distancerende fortællerkommentarer:

»Denne filosofi var måske sand, men den var af en sådan art at han ønskede at han var død. (...) Mangelen på motion, begyndte at undergrave hans helbred og gav ham den samme eksalterede og svage karakter som en tysk student. Han mistede den mandlige overlegenhed som med en energisk ed forjager visse usømmelige tanker der angriber ulykkelige menneskers sjæle. (...) den dårlige luft i kachotten gjorde sin virkning, han blev dårligere til at tænke. «5

Fortæller og helt er på dette tidspunkt i romanen på samme vidensniveau. Det tragiske ved udvekslingen er, at Juliens erkendelser faktisk kunne være udtalt af fortælleren tidligere i romanen. Juliens ønske om at vende tilbage til landet og leve sammen med Mme de Rênal, hans had til civilisationen, til hykleriet, og hans sandhedskærlighed er en fuldstændig gentagelse af de holdninger, som fortælleren har udtrykt i løbet af romanen. Denne gentagelse kaster et ironisk skær over fortællerens distancerende kommentarer. Fader/søn 
forholdet mellem fortæller og helt viser sig altså også ved en form for gentagelsesstruktur. Ligesom i en traditionel dannelsesroman tilnærmer Julien sig fortællerens faderlige orden mod slutningen af romanen, men erkendelserne virker underligt impotente og meningsløse, som de udtrykkes i fængslet, kort før han halshugges, og fortællerens skepsis og mangel på empati gør det blot mere tragisk. Det er Julien og ikke fortælleren, der halshugges. Stendhals ønske om at frigøre sig fra Rousseaus idealisme viser sig også i denne udveksling. Fortællerens forankring i en romantisk diskurs udstilles, fordi han udviser en modstand i forhold til Juliens realistiske indsigt, en indsigt der er uden kraft, for Juliens anagnorisis og dannelse fører blot til afmagt. Indsigten i, at lov og ret mangler et moralsk og naturligt grundlag, fører til en moralsk ensomhed, der tømmer ham for energi.

\section{Den historiske fortæller}

De tre analyser af fortællerens rolle i romanen har vist tre måder, hvorpå fortælleren er historiseret. Prendergast viser, hvordan fortælleren som en »formidler af doxa" manipulerer den offentlige opinion i restaurationsperioden ved at veksle mellem en sandsynlig og en usandsynlig repræsentation. Brooks forankrer forholdet mellem fortæller og helt i restaurationsperiodens legitimitetsproblemer, og jeg har forbundet fortællerens ideologi med en særlig romantisk diskurs fra Rousseau. Prendergasts og Brooks' tilgang til Rødt og sort er forskellige. Den ene undersøger romanen ud fra en statisk strukturalistisk vinkel, den anden ud fra en dynamisk psykologisk. Men deres syn på fortælleren som en magtinstans skaber en ensartethed i den måde romanen historiseres. For begge læsninger bevæger sig inden for det samme betydningsunivers, der skabes af de semantiske modsætningspar autoritet/frihed og undertrykkelse/oprør. Romanens politiske potentiale fødes af de konflikter, der opstår mellem henholdsvis fortæller og doxa og fortæller og legitimitetsproblemet. Ved at flytte fokus og analysere fortællerens engagement i romanen og hans værdier opstår der et andet fortolkningspotentiale. Fortællerens forankring i en romantisk diskurs bringer ham i spil med handlingen og gør ham til en del af romanens kritik af Rousseaus idealisme.

De tre historiseringer viser også de problemer, man traditionelt har haft med at placere Stendhal litteraturhistorisk. For analyserne af fortælleren har alle vist Stendhal som romantiker i modsætning til Stendhal som realist. Realisten Stendhal er i Georg Lukács' forståelse det klartskuende og rationelle intellekt, der med historisk og psykologisk indsigt skaber sociale typer som parvenuen Valenod, den borgerlige borgmester de Rênal og aristokraterne 
Marquis og Mathilde de la Mole. ${ }^{36}$ Den moralske fortæller, iscenesættelsen af de usandsynlige hændelser og destabiliseringen af fortællerens autoritet står i kontrast til den realistiske repræsentation. Den flertydige fortællerinstans er en af grundene til Stendhals uafklarede position mellem romantik og realisme.

\section{Noter}

1. Stendhal: Le Rouge et le Noir, Garnier Flammarion, Paris 1964. Jeg citerer fra Lars Bonnevies udmærkede nyoversættelse Rødt og sort, København 2000, p. 76.

2. Victor Brombert: "Les procédés d'intervention« in Stendhal et la voie oblique, Paris 1954, pp. 13-61. Georges Blin: „Les intrusions d'auteur« in Stendhal et les problèmes du roman, Paris 1954, pp. 179-322.

3. Wayne Booth: The Rhetoric of Fiction, London 1991, pp. 158-159.

4. Christopher Prendergast: "Stendhal: The ethics of verisimilitude«, in The order of Mimesis, London 1986. Peter Brooks: »The Novel and the Guillotine, or Fathers and Sons in Le Rouge et le noir«, in Reading for the Plot, New York 1984. Citaterne herfra er i min egen oversættelse.

5. Refereret i Dorrit Cohn: The Distinction of Fiction, USA 2000, p. 122.

6. Stendhal, p. 11.

7. Op.cit., p. 10.

8. Prendergast, p. 124.

9. Prendergast, pp. 12-23.

10. Roland Barthes: »Diderot, Brect, Eisenstein«, in Image-Music-Text, Fontana 1975, pp. 70-71. Prendergast, pp. 27-31.

11. Stendhal, pp. 331-332.

12. Prendergast, p. 127.

13. Op.cit., p. 132.

14. Stendhal, p. 184.

15. Op.cit., p. 7.

16. Op.cit., p. 8.

17. Op.cit., p. 12.

18. Op.cit., pp. 423, 436, 466 og 468.

19. Op.cit., p. 5l. På dansk lyder sætningen »og det blandt verdens smukkeste bjerge« en smule ironisk på grund af pronominet »det«. Tonen er ikke tilsvarende ironisk i den franske tekst: „Après tant de contrainte et de politique habile, seul, loin des regards des hommes, et, par instinct, ne craignant point Mme de Rênal, il se livrait au plaisir d'exister, si vif à cet âge, et au milieu des plus belle montagnes du monde." Le Rouge et le Noir, pp. 77-78. Raymond Trousson har vist, hvorledes beskrivelsen af forholdet mellem Julien og Mme de Rênal og særligt oplevelserne i Vergy er influeret af Rousseaus værker La Nouvelle Héloise og Confessions. Trousson mener, at Stendhal dekonstruerer Rousseaus idylliske naturbilleder. Det er en del af Stendhals forsøg på at distancere sig fra en »rousseauisme«. Trousson beskriver dog ikke fortællerens position i forhold til det fortalte. Raymond Trousson: Stendhal et Rousseau, Genève 1999, pp. 117-139.

20. Trousson, pp. 117-122. 
21. Stendhal, p. 215.

22. Stendhal er forfatteren Marie-Henri Beyles foretrukne pseudonym. Beyle brugte op mod 200 forskellige pseudonymer. Han er berømt for sine mange maskeringer.

23. Trousson, pp. 2 og 138-139.

24. Stendhal, p. 276.

25. Brooks, pp. 62-80.

26. Brooks, p. 76.

27. Op.cit., p. 67.

28. Dominique LaCapra er den kritiker, der mig bekendt har givet den mest rimelige psykologiske forklaring på skuddet. I Juliens liv er fraværet af moderen påfaldende. Den ældre Mme de Rênal er moderfiguren i hans liv, og hun er den eneste, der elsker ham for hans indre, som en god og følsom dreng. I det øjeblik hun beskriver ham i det sprog, som den ydre verden ser ham i, kollapser adskillelsen mellem det indre og det ydre, som han har foretaget for at få succes. Han bliver i satresk forstand defineret af sine handlinger, og hans ydre bliver hans indre, et uacceptabelt indre. Dominick LaCapra: History, Politics and the Novel, USA 1987, pp. 26-27.

29. Brooks, p. 86.

30. Cohn op.cit., p. 171.

31. Stendhal, p. 446.

32. Op.cit., p. 427.

33. Op.cit., p. 460.

34. Op.cit., p. 461-463.

35. Op.cit., p. 461-464.

36. Georg Lukács: Studies in European realism, London 1972, pp. 79-81. 